\title{
Assessment of Nine Micronutrients in Jasmine 85 Rice Grown in Ghana Using Neutron Activation Analysis
}

\author{
Michael Kwame Vowotor ${ }^{1}$, George Amoako ${ }^{1}$, Baah Sefa-Ntiri ${ }^{1}$, Samuel Amoah ${ }^{1}$, Samuel Sonko Sackey ${ }^{2} \&$ \\ Charles Lloyd Yeboah Amuah ${ }^{2}$ \\ ${ }^{1}$ Department of Physics, University of Cape Coast, Ghana \\ ${ }^{2}$ Laser and Fibre Optics Centre, Department of Physics, University of Cape Coast, Ghana \\ Correspondence: Michael Kwame Vowotor, Department of Physics, University of Cape Coast, Ghana. E-mail: \\ mvowotor@ucc.edu.gh
}

Received: April 5, 2020

Accepted: May 30, $2020 \quad$ Online Published: September 28, 2020

doi:10.5539/ep.v9n2p29

URL: https://doi.org/10.5539/ep.v9n2p29

\begin{abstract}
The amount of micronutrients in food is a key factor that determines the health status of a person. The concentrations of nine micronutrients, Sodium (Na), Magnesium (Mg), Chlorine ( $\mathrm{Cl})$, Potassium $(\mathrm{K})$, Calcium $(\mathrm{Ca})$, Vanadium $(\mathrm{V})$, Manganese $(\mathrm{Mn})$, Copper $(\mathrm{Cu})$ and Iodine $(\mathrm{I})$, in polished Jasmine 85 rice, locally cultivated in five rice farming areas in Ghana (Afienya, Afife, Dawhenya, Ashaiman and Aveyime), were determined using Neutron Activation Analysis. The standard materials used as reference were the International Atomic Energy Agency (IAEA)-530 Tuna fish homogenate and the National Institute of Standard and Technology (NIST) USA $1566 \mathrm{~b}$ Oyster Tissue. Recoveries of the elemental concentrations ranged from $88 \%$ to $111 \%$ of the certified values. Relative standardization method was used in the quantification of the elements. The range of concentrations measured in the rice are: $142.3-188.1 \mathrm{mg} / \mathrm{kg}$ for $\mathrm{Na}, 483.2-875.7 \mathrm{mg} / \mathrm{kg}$ for $\mathrm{Mg}, 465.6-718.0 \mathrm{mg} / \mathrm{kg}$ for Cl, 514.6$2949.0 \mathrm{mg} / \mathrm{kg}$ for K, $2303.0-2622.0 \mathrm{mg} / \mathrm{kg}$ for Ca, $0.0698-0.1925 \mathrm{mg} / \mathrm{kg}$ for $\mathrm{V}, 9.956-14.460 \mathrm{mg} / \mathrm{kg}$ for Mn, $0.8728-1.6790 \mathrm{mg} / \mathrm{kg}$ for $\mathrm{Cu}$ and $0.1181-0.1447 \mathrm{mg} / \mathrm{kg}$ for I. Using Hierarchical clustering analysis and Principal Component Analysis to evaluate the intensities of measured concentrations, $\mathrm{K}$ was established to be the most abundant, and was used to categorize two distinct clusters; Group 1 farms (Ashaiman, Afienya, and Dawhenya) and Group 2 farms (Aveyime and Afife). Group 2 farms recorded elevated intensities of micronutrients. With Pearson's correlation coefficient, some noteworthy correlations realized were between $\mathrm{Na}$ and $\mathrm{K}(\mathrm{r}=0.951), \mathrm{Na}$ and $\mathrm{V}(\mathrm{r}=0.842)$ and $\mathrm{K}$ and $\mathrm{V}(\mathrm{r}=0.812)$. This indicated the same or similar source inputs for each pair. The calculated mean daily intake of K exceeded the mean Recommended Dietary Allowable and Adequate Intake for all Life Stage Groups. Estimated health risk associated with the consumption of rice was only present for children between the ages of 1 and 3 for $\mathrm{Mg}$. The information on these nine micronutrients content of the rice from these five farming areas would be valuable in rice consumption studies to evaluate the overall availability of micronutrients to the Ghanaian populace and age groups and also in nutrition planning for analysis of nationwide rice supplies, mainly for regions and countries known to be susceptible to deficiencies of these micronutrients. The techniques espoused in this research can be used to accurately determine the concentration of micronutrients in rice and also trace the area where the rice was produced.
\end{abstract}

Keywords: micronutrients, trace elements, Polished Jasmine 85 Rice, neutron activation analysis, recommended daily allowance, GHARR-1

\section{Introduction}

Rice is whole and a broken kernel obtained from the species Oryza sativa $\mathrm{L}$ and is the second-largest grain produced in the world (Codex, 1996; Abbas, Atiq-ur-Rahman, Manzoor and Farroq, 2015). Polished rice is rice that has been milled to take out the husk, bran, germ, and has diverse amounts of the nutrients contained in them, leaving a starch-rich grain or seed with a bright, white, shiny appearance. This modifies the flavor, quality, and look of the rice, and helps check spoilage and improve its shelf life (Thomas, 2019; White rice, 2019). Jasmine 85 is among the liked, and therefore extensively grown rice type in Ghana (Akintayo, Maalekuu,and Saajah,2019).After maize, rice is currently the second most essential food staple in Ghana, with its intake increasing because of the growth in population. The nation's value of rice imports has escalated eight-fold in 7 years - from US\$152million in 2007 to a peak of US\$1.2billion in both 2014 and 2015 (Ghana Export Promotion 
Authority, 2018). The per capita rice consumption in $2016 / 17$ is estimated at about $35 \mathrm{~kg} / \mathrm{year}$, with Ghana's population at 28.2 million (Global Agricultural Information Network, 2018).

Rice is the most eaten standard diet in the world supplying over $21 \%$ of the calorie intake of the world's populace. It is therefore necessary to know some of the micronutrients in it. A summary of the functions and effects of the nine micronutrients on the human body studied are as shown in Table 1.

Table 1. Functions and effects of the nine micronutrients on the human body

\begin{tabular}{|c|c|c|c|}
\hline Element & Function & Adverse Effect of Deficiency & $\begin{array}{l}\text { Adverse Effect of Excessive } \\
\text { Consumption }\end{array}$ \\
\hline \multirow[t]{2}{*}{$\mathbf{N a}$} & $\begin{array}{l}\text { Major ion of the extra cellular } \\
\text { fluid. Assists nerve impulse } \\
\text { transmission }\end{array}$ & $\begin{array}{l}\text { Hyponatremia; similar symptoms due } \\
\text { to dehydration, and in extreme cases } \\
\text { the brain may swell and may cause } \\
\text { headaches, seizures, coma and even } \\
\text { death }\end{array}$ & $\begin{array}{l}\text { High blood pressure in susceptible } \\
\text { people, can lead to an increase in loss } \\
\text { of calcium in urine and increases the } \\
\text { amount of water the body, thus causing } \\
\text { the swelling of the legs and hands }\end{array}$ \\
\hline & (Health supplements nutritional g & ide 2017 .The Nationol 1 codemies 200 & ; Palsdottir, 2016) \\
\hline Mg & $\begin{array}{l}\text { Maintains normal nerve and } \\
\text { muscle function, supports } \\
\text { healthy immune system, keeps } \\
\text { heart beat steady, and helps in } \\
\text { strong bones, help regulate } \\
\text { blood glucose levels and aids in } \\
\text { the production of energy and } \\
\text { protein. }\end{array}$ & $\begin{array}{l}\text { Anorexia, confusion, delirium, rapid } \\
\text { heartbeat, hallucinations, fatigue, } \\
\text { insomnia, irritability, muscle } \\
\text { twitching, numbness, poor memory, } \\
\text { continued muscle contraction }\end{array}$ & $\begin{array}{l}\text { Diarrhoea, abdominal cramping, } \\
\text { nausea, stomach upset, vomiting, } \\
\text { affects the cardiovascular system, } \\
\text { muscle weakness and difficulty in } \\
\text { breathing, affects the balance of other } \\
\text { minerals in the body, changes in } \\
\text { mental status }\end{array}$ \\
\hline
\end{tabular}

(Busse, 2015; National Health and Medical Research Council [NHRMC], 2015)

Cl Maintains proper blood volume Heavy sweating, congestive heart Coughing, symptoms of asthma such and pressure, keeps amount of failure, over-hydration, Addison's fluid in and around cells in disease, certain kidney disorders, most balance, critical component of often seen in infants on chloridestomach hydrochloric acid, deficient formulae as wheezing and tightness of the chest, blurred vision, redness, and blisters on the skin, sensation of burning in the conserves potassium in body

(Nutritional Health Resource, 2017)

\begin{tabular}{lll}
\hline $\mathbf{K}$ & Help regulate fluid balance, Muscle weakness & Tiredness or weakness, feel some \\
& blood pressure and water & numbness or tingling, nausea or \\
& retention, nerve signals, and & vomiting, difficulty in breathing, pain \\
muscle contractions, protect & in the chest, palpitations or uneven \\
& against stroke and prevent & heartbeats. \\
&
\end{tabular}

1 (Raman, 2017)

Ca Regulation of heartbeat and Fainting, heart failure, brittle nails, Nausea, vomiting, constipation, blood clotting, building and chest pains, numbness and tingling muscle weakness, bone pain increased maintaining bones and teeth, sensations around the mouth, toes and thirst or urination helps body enzymes, help fingers, wheezing, coarse hair, muscle protect against over 10 different cramps and weakness, bone fractures 


\begin{tabular}{|c|c|c|c|}
\hline & $\begin{array}{l}\text { types of cancer, the most } \\
\text { common being prostate, breast, } \\
\text { lung and colorectal, helps in the } \\
\text { release of neurotransmitters and } \\
\text { contraction of muscles }\end{array}$ & $\begin{array}{l}\text { and tooth decay, fatigue, cataracts, } \\
\text { impaired intellectual, dry skin, } \\
\text { capacity, seizures, depression, chronic } \\
\text { itching, irritability / anxiety }\end{array}$ & \\
\hline & (Sharecare, 2019; University Heal & h News, 2019, Davis, 2019) & \\
\hline \multirow[t]{2}{*}{$\mathbf{V}$} & $\begin{array}{l}\text { Controls blood sugar levels, } \\
\text { retards tumour growth. }\end{array}$ & $\begin{array}{l}\text { Kidney and heart disease, low blood } \\
\text { sugar levels. }\end{array}$ & $\begin{array}{l}\text { Elevation in blood pressure, abdominal } \\
\text { cramps, diarrhoea. }\end{array}$ \\
\hline & \multicolumn{3}{|l|}{ (Murray, 2005; Tracey et al., 2007) } \\
\hline \multirow[t]{2}{*}{ Mn } & $\begin{array}{l}\text { Helps bone formation and the } \\
\text { action of some enzymes such as } \\
\text { those involved in carbohydrate } \\
\text { metabolism }\end{array}$ & $\begin{array}{l}\text { Obesity, birth defects, changes of hair } \\
\text { colour, abnormal bone function and } \\
\text { cartilage, growth retardation. }\end{array}$ & $\begin{array}{l}\text { Neurotoxicity and elevated blood } \\
\text { concentration, high incidence of } \\
\text { pneumonia and other upper respiratory } \\
\text { infections }\end{array}$ \\
\hline & (Lenntech, 2019) & & \\
\hline \multirow[t]{2}{*}{$\mathrm{Cu}$} & $\begin{array}{l}\text { Fixes calcium in the bones and } \\
\text { to build and repair all connective } \\
\text { tissue (tendons, ligaments, skin, } \\
\text { hair, nails, arteries, veins). }\end{array}$ & $\begin{array}{l}\text { Low libido in women and. Increases } \\
\text { the lipid peroxidation in the heart in } 2 \text { - } \\
\text { folds. }\end{array}$ & $\begin{array}{l}\text { Vomiting, nausea, sleep disorder, } \\
\text { abdominal pain, homosexual desire, } \\
\text { weakness, menstrual cramps, and } \\
\text { metallic taste in the mouth,liver and } \\
\text { kidney damage. }\end{array}$ \\
\hline & (Nolan, 1983) & & \\
\hline I & $\begin{array}{l}\text { Utilized by the thyroid gland for } \\
\text { the biosynthesis of the thyroid } \\
\text { hormones since every cell in the } \\
\text { body depends upon thyroid } \\
\text { hormones for its metabolism. }\end{array}$ & $\begin{array}{l}\text { Abortions, Goitre, Stillbirths, Infant } \\
\text { Mortality, Mental deficiency, anger, } \\
\text { obesity, dwarfism, } \\
\text { Congenitalanomalies, Psychomotor } \\
\text { defects, hypothyroidism. }\end{array}$ & $\begin{array}{l}\text { Thyroid gland inflammation, same } \\
\text { symptoms as iodine deficiency, } \\
\text { including goitre (an enlarged thyroid } \\
\text { gland) and thyroid cancer. }\end{array}$ \\
\hline
\end{tabular}

In this study, polished Jasmine 85 rice samples collected from five rice farms in five towns in Ghana, (Afienya, Afife, Dawhenya, Ashaiman and Aveyime), have been analyzed for nine elemental micronutrients content (Sodium (Na), Magnesium (Mg), Chlorine (Cl), Potassium (K), Calcium (Ca), Vanadium (V), Manganese (Mn), Copper $(\mathrm{Cu})$ and Iodine (I)). . The technique being used in establishing the concentrations in the rice is Neutron Activation Analysis (NAA). The sources of these elements will also be ascertained by establishing the relationship between them if any.

Neutron Activation Analysis is a nuclear technique applied for determining concentrations of elements and allows for the distinct selection of elements as it discounts the chemical form of the sample and concentrates only on its nucleus. Its strengths are that it needs no chemical preparation, is non-destructive and has very low detection limits for many elements. It can also be used for small sample sizes (1-200 mg) and can be employed to analyze many of elements at the same time. On the order of nano-gram scale, this technique offers sensitivities better than that achieved by other procedures. It has been established as the 'referee method' as it is reliable and exact, and used when new procedures are to be developed or when other techniques produce diverse results (Ali, 1999). Comparatively, NAA is less expensive relative to other analytical methods (Vowotor et al, 2012).

\section{Materials and Methods}

\subsection{Study Area}

Rice samples were obtained from different five rice farms in the south-eastern parts of Ghana(Figure 1). These are the main areas in Ghana that grow rice. Ashaiman is located between coordinates $5^{\circ} 40^{\prime}$ and $5^{\circ} 43^{\prime} \mathrm{N}$ of latitude and longitudes $0^{\circ} 05^{\prime}$ and $0^{\circ} 07^{\prime} \mathrm{E}$. It is $26 \mathrm{~km}$ North-East of Accra located north of Tema on the northern borders 
of Tema community in the Greater Accra region of Ghana. Afife is situated in the Volta Region of Ghana amid latitudes $6^{\circ} 04^{\prime}$ and $6^{\circ} 08^{\prime}$ and longitudes $0^{\circ} 45^{\prime}$ and $0^{\circ} 55^{\prime}$ East, $162 \mathrm{~km}$ east of Accra. Aveyime is found in the Volta region with a distance of $85 \mathrm{~km}$ from Accra. Afienya is a town $41.4 \mathrm{~km}$ from Accra in the same longitude with Ashaiman. Finally, Dawhenya, which is $6 \mathrm{~km}$ from Accra and sharing the latitude with Ashaiman.

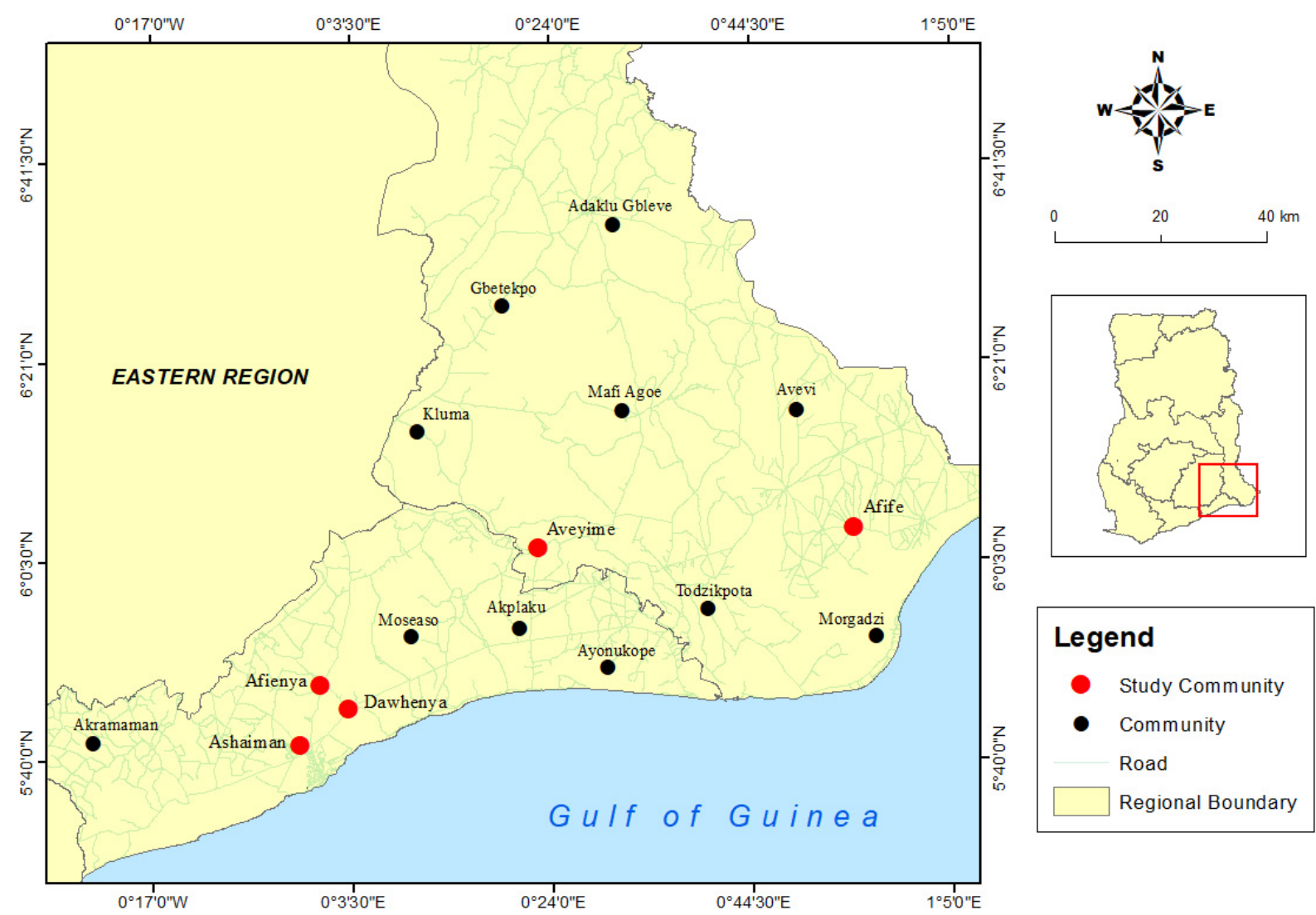

Figure 1. A map of towns in south-eastern Ghana with rice farms

\subsubsection{Sampling and Sample Collection}

The sampling equipment and containers were treated heavy metal-grade acetone before and after use. Additionally, all containers were rinsed with heavy metal-grade hydrochloric acid $(\mathrm{HCl})$ before placing samples in them. Blank determinations were conducted for quality control. Polished Jasmine 85 Rice samples were randomly collected in three different areas within all the farm warehouses. At each farm, the three site-collected samples were put in one bowl and mixed together to form a composite sample. The composite polished Jasmine 85 Rice samples were then put into a plastic container, coded with a permanent marker and placed in a labeled Ziploc bag to avoid crosscontamination. They were then kept in a cool condition and sent to the Ghana Atomic Energy Commission (GAEC) Preparation Laboratory for analyses. During NAA (Figure 2), a neutron interacts with the target nucleus through a non-elastic collision, and a compound nucleus forms in an excited state. 


\subsection{Overview of Neutron Activation Analyses Technique Used}

\subsubsection{Neutron Activation Analysis}

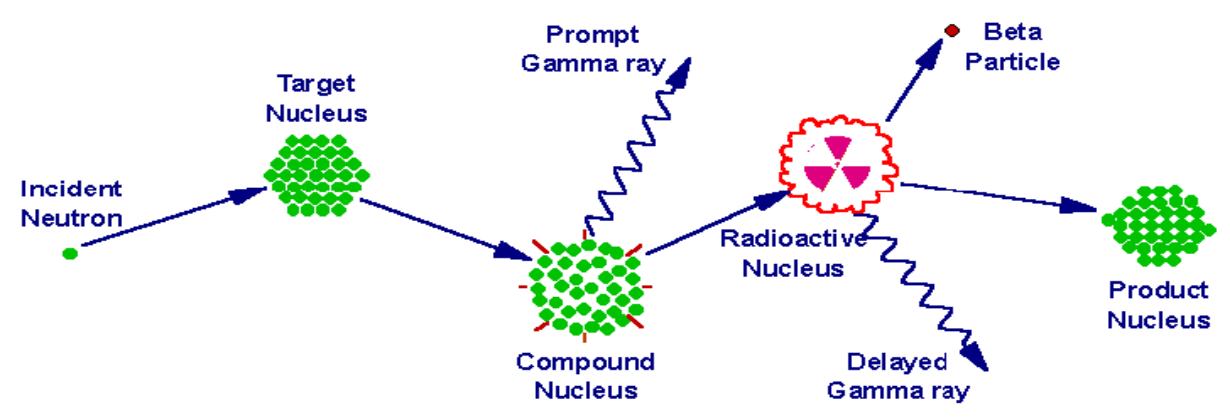

Figure 2. A process of neutron capture then the emission of gamma rays (Glascock, 2003)

The excitation energy of the compound nucleus is as a result of the binding energy of the neutron with the nucleus. The compound nucleus will almost immediately de-excite into a more stable form through the emission of one or more distinctive gamma rays. Most often, this new configuration produces a radioactive nucleus that also decays by the release of one or more typical delayed gamma rays. This is done at a much measured rate according to the half-life of the radioactive nucleus. Depending on the specific radioactive species, half-lives could range from a portion of a second to some years (Ali, 1999).

\subsubsection{Relative Standardization}

In using this method, a chemical standard (index std) of known mass, Wstd, of the element is co-irradiated with the sample of unknown mass Wsam. When the samples to be irradiated are short-lived radionuclide, both the standard and sample are irradiated independently under the equal conditions, normally with a monitor of the same neutron fluence rate and both are tallied in the same geometrical arrangements with respect to the gamma-ray energy. The neutron flux, cross-section, irradiation times and all other parameters associated with counting are assumed to be the same for the standard and sample at a particular sample-to-detector geometry. With this assumption, the neutron activation equation then reduces to:

$$
\rho_{\text {sam }}=\frac{\left[\left(P_{A} / t_{C}\right)\right]_{\text {sam }}[\rho C D W]_{s t d}}{\left.\left[P_{A} / t_{C}\right)\right]_{\text {std }}[C D W]_{\text {sam }}}
$$

where $\left(\mathrm{P}_{\mathrm{A}} / \mathrm{t}_{\mathrm{c}}\right)$ std and $\left(\mathrm{P}_{\mathrm{A}} / \mathrm{t}_{\mathrm{c}}\right)$ sam are the counting rates for the standard and sample respectively, $\rho_{\text {std }}$ and $\rho_{\text {sam }}$ are the counting concentrations of the standard and the element of interest respectively, $\mathrm{C}_{\text {std }}$ and $\mathrm{Cs}_{\mathrm{am}}$ are the counting factors for standard and sample, $\mathrm{D}_{\text {std }}$ and $\mathrm{D}_{\text {sam }}$ are the decay factors for the standard and sample respectively.

\subsection{Experimental Procedure}

Fifty (50) $\mathrm{mg}$ in 3 replicates for each sample collected at each farm was weighed and packaged in a transparent polyethylene film. The samples were shaken to guarantee consistency before weighing, after which they were encapsulated into irradiation capsules (Rabbit capsule) of diameter $1.6 \mathrm{~cm}$ and height $5.5 \mathrm{~cm}$ and heat-sealed for neutron activation (irradiation).

To ensure quality assurance, IAEA-530, Trace element in tuna fish homogenate, Certificate of analysis standard material 1566b Oyster Tissue (National Institute of Standards and Technology) prepared in the same manner as the study samples were included. Recoveries of the elemental concentrations ranged from $88 \%$ to $111 \%$ of the certified values. 
Table 2. Nuclear data of the seven elements

\begin{tabular}{cclllll}
\hline Element & Radioisotope & $\begin{array}{l}\text { Gamma Ray } \\
\text { Energy }(\mathbf{k e V})\end{array}$ & Half-life & $\begin{array}{l}\text { Irradiation } \\
\text { Time }\end{array}$ & $\begin{array}{l}\text { Counting } \\
\text { Time }\end{array}$ & $\begin{array}{l}\text { DL } \\
(\boldsymbol{\mu g} / \mathbf{g})\end{array}$ \\
\hline $\mathbf{N a}$ & ${ }^{24} \mathrm{Na}$ & 2754.0 & $15 \mathrm{hr}$ & $10 \mathrm{mim}$ & $10 \mathrm{mim}$ & 0.001 \\
$\mathbf{M g}$ & ${ }^{27} \mathrm{Mg}$ & 1014.4 & $9.46 \mathrm{~min}$ & $10 \mathrm{mim}$ & $10 \mathrm{mim}$ & 0.1 \\
$\mathbf{C l}$ & ${ }^{38} \mathrm{Cl}$ & 1642.4 & $37.3 \mathrm{~min}$ & $10 \mathrm{mim}$ & $10 \mathrm{mim}$ & 0.001 \\
$\mathbf{K}$ & ${ }^{42} \mathrm{~K}$ & 1524.6 & $12.4 \mathrm{hr}$ & $10 \mathrm{mim}$ & $10 \mathrm{mim}$ & 0.01 \\
$\mathbf{C a}$ & ${ }^{49} \mathrm{Ca}$ & 3084.5 & $8.72 \mathrm{~min}$ & $10 \mathrm{mim}$ & $10 \mathrm{mim}$ & 1.0 \\
$\mathbf{V}$ & ${ }^{52} \mathrm{~V}$ & 1434.1 & $3.76 \mathrm{~min}$ & $10 \mathrm{mim}$ & $10 \mathrm{mim}$ & 0.001 \\
$\mathbf{M n}$ & ${ }^{56} \mathrm{Mn}$ & 1810.7 & $2.58 \mathrm{hr}$ & $10 \mathrm{mim}$ & $10 \mathrm{mim}$ & 0.0001 \\
$\mathbf{C u}$ & ${ }^{66} \mathrm{Cu}$ & 1039.2 & $5.1 \mathrm{~min}$ & $10 \mathrm{mim}$ & $10 \mathrm{mim}$ & 0.01 \\
$\mathbf{I}$ & ${ }^{128} \mathrm{I}$ & 440.9 & $25 \mathrm{~min}$ & $10 \mathrm{mim}$ & $10 \mathrm{mim}$ & 0.0001 \\
\hline
\end{tabular}

The samples and reference standards were irradiated in the GHARR-1 facility using light-water as moderator and coolant and operated at $15 \mathrm{~kW}$ and at a thermal neutron flux of $5 \times 10^{11} \mathrm{ncm}^{-2} \mathrm{~s}^{-1}$. The samples were transferred into the irradiation sites through a pneumatic transfer system at a pressure of 0.6 MPa (Tandoh, Bredwa-Mensah, Dampare, Akaho, and Nyarko, 2009). Irradiation times ranged from $10 \mathrm{~s}$ to $1 \mathrm{~h}$ depending on the half-lives of the elements of interest. All elements have relatively short half-lives such as $\mathrm{Mg}, \mathrm{Mn}$, and $\mathrm{V}$, with half-lives between $2 \mathrm{~min}$ and $3 \mathrm{~h}$, irradiation time was $10 \mathrm{~s}$ and counting time $10 \mathrm{~min}$. The samples were analyzed using irradiation schemes by optimizing irradiation time $\left(t_{i}\right)$, decay time $\left(t_{d}\right)$ and counting time $\left(t_{c}\right)$ based on the half-life of the respective elements. The irradiation scheme was $\left(t_{\mathrm{i}}: t_{\mathrm{d}}: t_{\mathrm{c}}=0.5-2: 1: 10 \mathrm{~min}\right)$. The nuclear data of elements of interest have been summarized as shown in Table 2 .

\subsubsection{Qualitative and Quantitative Analysis}

The qualitative study entails determination of the seven elements in the breast milk samples by the identification of the spectra peaks and assigning corresponding radionuclides and hence the elements present. The quantitative analysis involves the calculation of the areas under the peaks of the identified elements and converting them into concentrations using an appropriate software or equation(s) (Alfassi, 1994). The tallying of the induced radioactivity was carried out by a PC-based $\gamma$-ray spectrometry. This is made up of an n-type high purity Germanium (HPGe) detector (model GR2518) connected to a computer-based Multichannel Analyzer through electronic modules and a spectroscopy amplifier (model 2020, Canberra Industries Incorporated). The relative efficiency of the detector is $25 \%$ with energy resolution of $1.8 \mathrm{KeV}$ at $\gamma$-ray energy of $1332 \mathrm{KeV}$ of ${ }^{60} \mathrm{Co}$. The qualitative analysis was achieved by means of ORTEC EMCAPLUS Multichannel Analyzer (MCA) Emulation software. To analyse the spectrum, a Microsoft Window-based software, MAESTRO, was used (Adomako, Nyarko, Dampare, Serfor-Armah, Osae, Fianko, and Akaho, 2008), and was also used to identify the various photo peaks, and calculate the areas under them. The other quantitative measurements were done using the concentration equation (Equation 1) in a Microsoft Excel programme for calculating the elemental concentrations in $\mu \mathrm{g} / \mathrm{g}$. The detection limit (DL) of the detector for the various elements of interest has also been summarized in Table 2 . 
(a)

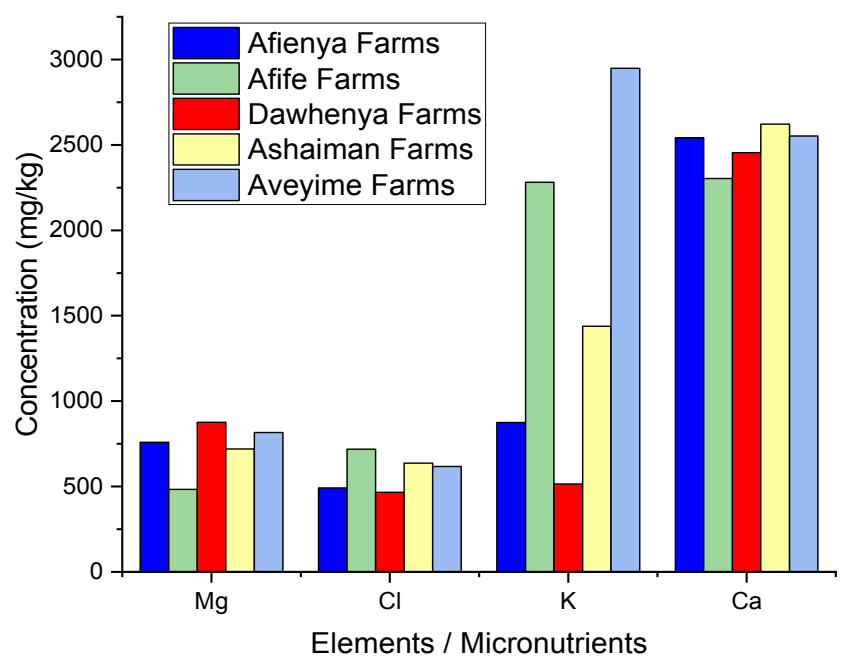

(b)

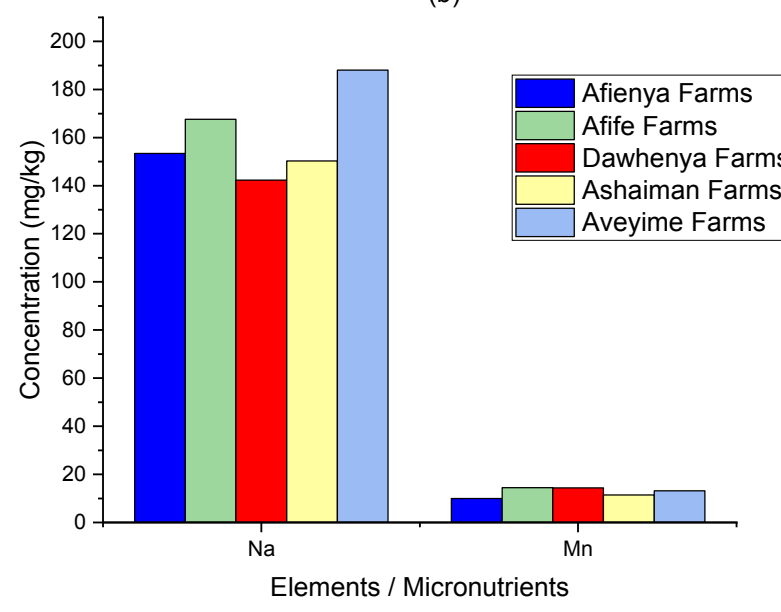

(c)

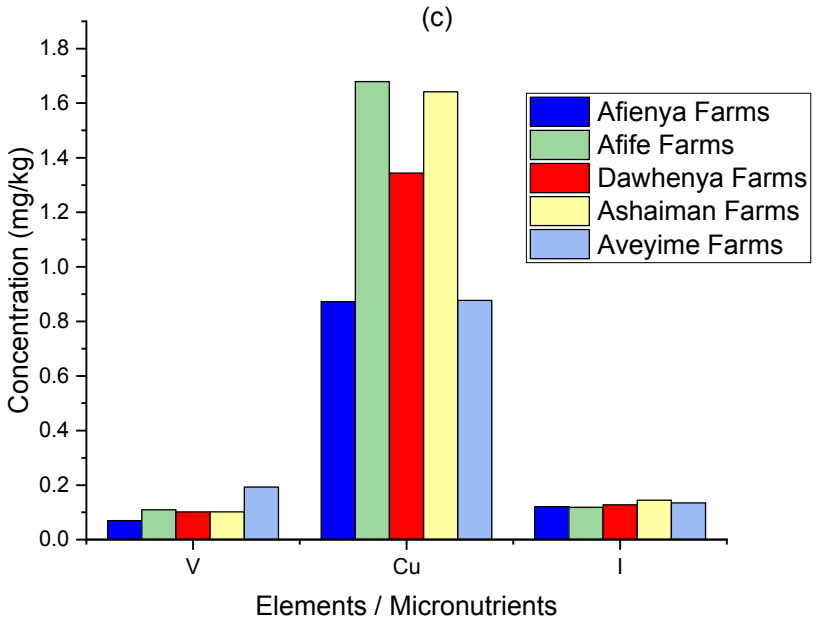

Figure 3. (a) Abundance of the individual elements $(\mathrm{Mg}, \mathrm{Cl}, \mathrm{K}$ and $\mathrm{Ca}$ ) at the five farms

(b) Abundance of the individual elements $(\mathrm{Na}$ and $\mathrm{Mn})$ at the five farms

(c) Abundance of the individual elements $(\mathrm{V}, \mathrm{Cu}$ and $\mathrm{I})$ at the five farms 


\section{Results and Discussions}

The mean concentrations of $\mathrm{Na}, \mathrm{Mg}, \mathrm{Cl}, \mathrm{K}, \mathrm{Ca}, \mathrm{V}, \mathrm{Mn}, \mathrm{Cu}$ and $\mathrm{I}$ at the five farms are presented in Figure 3.

\subsection{Statistical Analyses}

The initial descriptive statistics used include mean, standard deviation (SD), and minimum and maximum values. A Pearson correlation analysis was conducted among the 9 micronutrients in the rice. Principal component analysis was also conducted on the basis of the correlation matrix. Based on Dietary Reference Intake, Daily Average Intake was calculated and finally, the Hazard Index was calculated to estimate the daily intake level of the nine micronutrients that is to be expected to be without detrimental effects in a Life Stage Group.

\subsubsection{Assessments Carried Out}

\subsubsection{Assessment According to Micronutrient Concentration}

Figure 3 shows the total average mean concentrations of the micronutrients in $\mathrm{mg} / \mathrm{kg}$. The elemental composition of a plant reflects the composition of the soil it is found in, or another nutrient medium. Plants are selective in their absorption of elementsin a soil (Teherani, 1987), with their growth and maturity being dependent on the availability or otherwise, and the proportions in which micronutrients are present in the soil (Das, 2014). From Figure 3b, Rice from the Aveyime Farm has the highest quantity of Sodium whiles Dawhenya Farm recorded the least amount of Sodium concentration. On the other hand, Dawhenya had a maximum concentration of Magnesium while Afife had the least amount of Magnesium concentration. Although Afife Farms recorded the maximum amount of Chlorine concentration it also recorded the minimum amount of Calcium. Afife again had the minimum amount of Potassium and Calcium whiles Aveyime Farms and Ashaiman Farm recorded the highest amount of Potassium and Calcium respectively. The levels of Vanadium, Manganese, Copper, and Iodine were very low. Ghanaian foods have been observed to be very low in Iodine (Nyarko, Serfor-Armah, Akaho, Anim-Sampong, and Maakuu. 2002). Iodine deficiency has been identified as one of the factors that have an adverse effect on child development in developing countries (Walker et al., 2007). These deficiencies manifest as underdeveloped physical and mental growth as well as sterility, lethargy and cognitive injury (Aduand Simpson, 2017).

\subsubsection{Multivariate Analysis (Hierarchical Clustering Analysis (HCA))}

Hierarchical clustering analysis (HCA) is a multivariate technique which examines the inter point distances between samples and presents the information obtained in a form of a two-dimensional plot called a dendrogram. HCA technique forms clusters (groups) for samples based on the nearest in row spaces (Beebe, Pell, \& Seasholtz, 1998; Amuah, Eghan, Anderson, Adueming, \& Opoku-Ansah, 2017). The approach initially treat search sample as a cluster and then join the closest cluster together. The process is repeated until only one cluster remains. Figure 4 shows the HCA carried out on the concentration data to determine if any pattern that characterizes or separates the micronutrients at the various farms could be established.

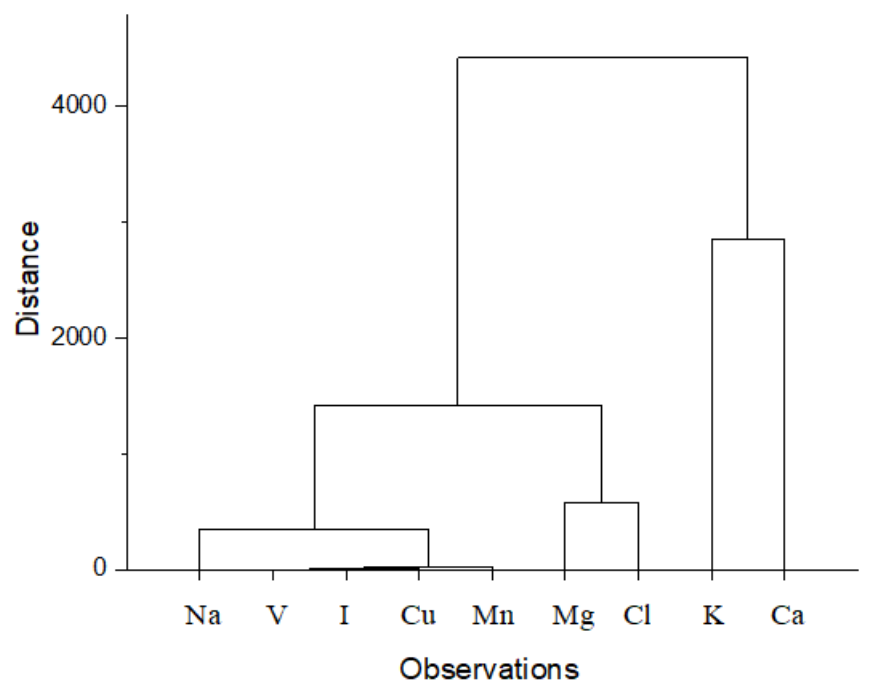

Figure 4. HCA results for the 9 micronutrients on the 5 farms

From Figure 4 two major clusters can be identified; Group 1 ( $\mathrm{K}$ and $\mathrm{Ca}$ ) and Group 2 (Na, V, I, $\mathrm{Cu}, \mathrm{Mn}, \mathrm{Mg}$, and $\mathrm{Cl})$. The inference, therefore, is that there is a common element that differentiates between these two groups. To 
know this element, and possibly which of the farms have more or less of it, Principal Component Analysis (PCA) was used (Figure 5).

\subsubsection{Multivariate Analysis (Principal Component Analysis)}

Principal Component Analysis (PCA) is a technique for multivariate analysis in which new 'axes' called principal components(PCs) are constructed by forming linear combinations of original variables (measured parameter). The first PC or PC1 contains the maximum variance from the data; followed by PC2 and so forth (Bro \&Smilde, 2014).

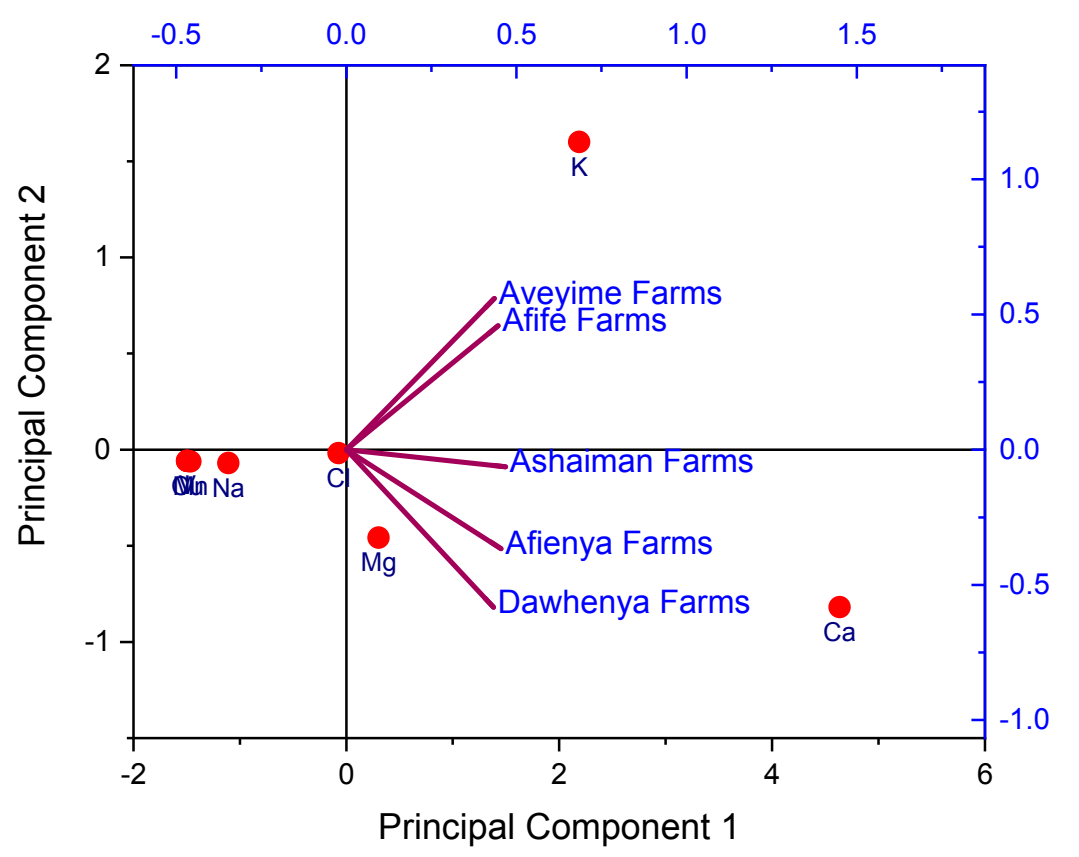

Figure 5. Biplot depicting the relationships between the farms (observations) and how the micronutrients (variables) contributed to the variations or similarities among the farms

A PCA score plot shows the levels of micronutrients are not the same in the rice for all farms. Two groupings can be identified in Figure 5. The first group of farms (Ashaiman, Afienya, and Dawhenya) are to the low or negative axis of the PC2 axis (vertical-axis) whiles the second group (Aveyime and Afife) are high or on the positive axis. It can be inferred that since the second group of farms is to the high side on the PC2 axis, then the major micronutrient causing the differences between these two groups is more in the second group (to the positive side on the PC2 axis) than the other group of farms to the negative side of the PC2 axis. The responsible micronutrient is $\mathrm{K}$ as it exhibits the maximum positive value along the PC2 axis. This is followed by $\mathrm{Ca}$ being the second responsible micronutrient exhibiting maximum positive value along the $\mathrm{PC} 2$ axis. The contribution of all the other micronutrient can also be inferred as follows $\mathrm{K}>\mathrm{Ca}>\mathrm{Mg}>\mathrm{Cl}>\mathrm{Na}>\mathrm{Mn}>\mathrm{Cu}>\mathrm{I}>\mathrm{V}$.

The contribution of all the other micronutrients can also be inferred. The micronutrient positioned at the origin of the PC Biplot $(\mathrm{Cl})$ have a neutral effect, whereas the micronutrients in the negative $(\mathrm{Ca}, \mathrm{Mg}, \mathrm{Na}, \mathrm{Mn}, \mathrm{Cu}, \mathrm{I}$ and $\mathrm{V})$ show an inverse relationship with the only micronutrient at the positive (K). None of the micronutrients positioned at the origin of the PC Biplot which means all the micronutrients were significant or does not have any neutral effect. Two other very useful deductions can be made from Figure 5. The first is that it is possible to trace the particular farm whose rice is based on the measured levels of micronutrients. For instance, a bowl of unknown rice which has high levels of I but relatively lower levels in $\mathrm{Mg}$ and $\mathrm{Ca}$ is most likely to come from Afienya farms or Dawhenya farms. The second deduction is that the type of micronutrients observed can be related to the activity that goes on around the farming area. For instance, apart from Aveyime farms and Afife farms which are high in $\mathrm{K}$ but low in the other micronutrients, Ashaiman farms, Afienya farms, and Dawhenya farms are high in all the micronutrients except K. It can also be inferred that since all the farms are to the right on the PC1 axis, then the major micronutrients running through the five farms are $\mathrm{K}, \mathrm{Mg}$ and $\mathrm{Ca}$. But the $\mathrm{PC}$ biplot has $\mathrm{K}$ as the most dominating micronutrient and is highly correlated with $\mathrm{Na}, \mathrm{Cl}$ and $\mathrm{V}$. These correlations are as shown in Table 3 
and explained after the table.

\subsubsection{Assessment according to Correlation between Elements}

Pearson's correlation coefficient was used to draw parallels between any two of the micronutrients. The matrix between the elements, shown in Table 3, gives information about their possible sources (Currie, 1991; Alfassi, 1994). The correlation coefficient which is significant at $95 \%$ confidence level, and could indicate the same or similar source input is highlighted in red and discussed. Though $95 \%$ confidence level was used to ascertain the strength of their relationship, there are other strongly correlated elements with high coefficients of determination, hence they cannot be ruled out and are also highlighted in blue, green and black. The focus would be on the strength of the relationship and while reporting statistical significance (Pallant, 2007). The interpretation of the strength of the correlation coefficients usually depends on the researcher, however, there are suggested guidelines. A correlation coefficient exactly \pm 1.0 depicts a perfect downhill/uphill (negative/positive) linear relationship; \pm 0.7 indicates a strong downhill/uphill (negative/positive) linear relationship; \pm 0.5 signifies a moderate downhill/uphill (negative/positive) relationship; \pm 0.3 signifies a weak downhill/uphill (negative/positive) linear relationship and 0 indicates the absence of a linear relationship (Rumsey, 2010).

The seasonal variation in the chemical make-up of plants has been previously studied (Cannon, Papp, and Anderson, 1972; Sauchelli, 1969). The absorption of the elements from the soil is regulated by many factors like the amount in the lithosphere, the form of an element, the $\mathrm{pH}$ of the soil, the physical condition of the soil, temperature, moisture content, the genetic constitution of the plant type (Teherani, 1987). Plants atimes undergo a phenomenon known as the Steenbjerg effect, where under acute deficiency conditions, it is likely that the decrease of the concentration of an element results in a small increase in growth (Bista, Heckathorn, Jayawardena, Mishra and Boldt, 2018). The intake of elements by plant roots consists of two phases: absorption and accumulation (Teherani, 1987). The interaction between ions can result in competition or competitive inhibition or in the stimulation of uptake (Hemphill, 1972). Discharges from groundwater are important sources of nutrients, trace elements and contaminants to many types of ecosystems (Kelly and Moran, 2002). It is therefore important to characterize each individual source of micronutrients and determine their input.

Table 3: Correlation matrix between the micronutrients in the rice samples

\begin{tabular}{crrrrrrrrr}
\hline & $\mathrm{Na}$ & $\mathrm{Mg}$ & $\mathrm{Cl}$ & $\mathrm{K}$ & $\mathrm{Ca}$ & $\mathrm{V}$ & $\mathrm{Mn}$ & $\mathrm{Cu}$ & $\mathrm{I}$ \\
\hline $\mathrm{Na}$ & \multicolumn{1}{c}{1} & & & & & & & & \\
$\mathrm{Mg}$ & -0.195 & 1 & & & & & & & \\
$\mathrm{Cl}$ & $\mathbf{0 . 5 4 9}$ & $-\mathbf{0 . 7 9 9}$ & 1 & & & & & & \\
$\mathrm{~K}$ & $\mathbf{0 . 9 5 1}$ & -0.380 & $\mathbf{0 . 7 6 7}$ & 1 & & & & & \\
$\mathrm{Ca}$ & -0.078 & $\mathbf{0 . 6 3 1}$ & -0.321 & -0.131 & 1 & & & & \\
$\mathrm{~V}$ & $\mathbf{0 . 8 4 2}$ & 0.186 & 0.353 & $\mathbf{0 . 8 1 2}$ & 0.104 & 1 & & & \\
$\mathrm{Mn}$ & 0.189 & -0.192 & 0.297 & 0.280 & $\mathbf{- 0 . 6 9 7}$ & 0.399 & 1 & & \\
$\mathrm{Cu}$ & -0.361 & $\mathbf{- 0 . 5 8 9}$ & $\mathbf{0 . 5 3 4}$ & -0.066 & -0.388 & -0.286 & 0.427 & 1 & \\
$\mathrm{I}$ & 0.014 & 0.405 & 0.100 & 0.125 & $\mathbf{0 . 7 8 0}$ & 0.357 & -0.195 & 0.118 & 1 \\
\hline & & & & & & & & & \\
\hline
\end{tabular}

Some of the significant correlations on Table 3 can be drawn between the micronutrients $\mathrm{Na}$ and $\mathrm{K}(\mathrm{r}=0.951)$, Na and $\mathrm{V}(\mathrm{r}=0.842)$ and $\mathrm{K}$ and $\mathrm{V}(\mathrm{r}=0.812)$. These pairs could each indicate the same or similar source inputs.

The high levels of $\mathrm{Mg}$ in the rice may be as a result of the activities of car mechanics along the banks of the rice farms. Magnesium is again used as an anode material in primary batteries due to its high standard potential. Magnesium/manganese dioxide $\left(\mathrm{Mg} / \mathrm{MnO}_{2}\right)$ battery has twice the service life capabilitycompared to zinc/manganese dioxide $\left(\mathrm{Zn} / \mathrm{MnO}_{2}\right)$ battery of the same size, and has a better ability to retain its capacity during storage, even at high temperature. $\mathrm{Mg} / \mathrm{MnO}_{2}$ battery is consequently more durable and better storable as it has a protective cover which is formed on the surface of the magnesium anode (Electrical4u, 2015). A critical screening of the debris along the farms revealed the presence of used, spoilt and discarded car batteries. This practice can explain the high levels of magnesium and manganese in the rice.

About $80 \%$ of vanadium turned out is exploited as a steel additive. Vanadium-steel alloys are tough and utilized for the construction of tools, armour plates, axles, piston-rods and crankshafts used in cars (Royal Society of 
Chemistry [RSC], 2015). Manganese in its pure state is too brittle to be of much use and as a result used in alloys such as steel. Steel, which has improved workability and resistance to wear, contains about $1 \%$ manganese. Manganese-steel contains about 13\% manganese (Royal Society of Chemistry [RSC], 2015). One can, therefore, infer that the high levels of $\mathrm{Mn}$ and $\mathrm{V}$ in the salt could be assigned to the same activities of car mechanics operating around the farms.

\subsubsection{Assessment According to Dietary Reference Intake}

Dietary Reference Intakes are a set of guiding principle for every day intake of nutrients (as vitamins, protein, and fats) and other food supplements (as fibre). It comprises suggested dietary allowances (RDA), adequate daily intake (AI), values for nutrients having undetermined recommended daily allowances and tolerable upper level (UL) values of dietary reference intake (DRI) (Merriam-Webster Medical Dictionary, 2015).

Recommended Dietary Allowable (RDA) is an intake level that meets specified criteria for adequacy, thereby minimizing the risk of nutrient deficiency or excesses. A Maximum Upper Intake Level (UL) is the maximum level of every day nutrient intake that is not likely to pose any adverse effect on health to an individual, and denotes complete intake from food, water, and other additions (Food and Nutrition Board, 2001; Institute of Medicine, 2001).

Adequate Intake (AI) is the suggested average daily nutrient ingestion level based on experimental approximations of nutrient intake by groups of apparently fit people who are thought to be maintaining a sufficient nutritional state. It is expected to meet the needs of most individuals in a specific life-stage and gender group (Institute of Medicine, 2001). The maximum Upper Limit (UL) of Recommended Dietary Allowable (RDA) and Adequate Intake (AI) for the Life Stage Groups of the elements investigated are presented in Table 1 in the Appendix.

Sodium is an electrolyte/mineral and a major ion of the extracellular fluid that aids nerve-impulse transmission (The National Academies, 2004; Nutritional Health Resource, 2010). For the most part, over 70\% of dietary sodium is obtained from eating packaged and prepared foods and not from salt added to food during cooking or when eating. The Daily Value for sodium is less than 2,300 milligrams (mg) per day (US FDA, 2019).

Chlorine is an electrolyte that works with potassium and sodium to regulate the amount of fluids in the body and its $\mathrm{pH}$ (Minerals Education Coalition, 2013). Table salt and many vegetables such as celery, tomatoes, lettuce, and seaweeds are high-quality sources of chloride. The recommended daily dose of elemental Chlorine is $3400 \mathrm{mg}$ per day (Lenntech B.V., 2019).

Practitioners are cautious to recommend oral Magnesium preparations as a result of its known side effect of causing diarrhoea. The suggested daily dose of elemental Magnesium is $400 \mathrm{mg}$ per day, with a single dose of 800-1600 mg being essential to produce a laxative result (Fine, 1991; Gums, 2004; Nishizawa, MoriiandDurlach, 2007).Food intake is the main source of Vanadium with its dietary intake estimated as $0.34 \mu \mathrm{g} / \mathrm{kg}$ (US EPA, 2015) and an Upper Tolerable Limit of $1.8 \mathrm{mg}$ /day (ATSDR, 2012; US Institute of Medicine, 2001).Potassium is the third most abundant mineral in your body and plays a relevant part in several body functions. A variety of whole foods are rich sources of potassium, including beet greens, yams, banana, avocado, potatoes and spinach (Healthline, 2019). Its daily intake is $3500 \mathrm{mg}$ (Lenntech B.V., 2019).

Studies have shown that both Calcium and Vitamin D are essential in building bone. Calcium can be found in many foods like Seafood and dairy (Harvard University, 2019). The recommended daily dose of elemental Calcium is $1000 \mathrm{mg}$ per day (Lenntech B.V., 2019). Manganese is an essential nutrient/mineral that is found in several foods including nuts, legumes, seeds, tea, whole grains, and leafy green vegetables (U.S. National Library of Medicine, 2019). Its daily intake is $5 \mathrm{mg}$ (Lenntech B.V., 2019).

Iodine is a vital trace element that plays a very important role in human physiological actions of thyroid hormones. Every cell in the body depends upon thyroid hormones for regulation of their metabolism and promotes growth and development in the body including the brain. (Endocrineweb, 2017). The leading preventable causes of brain damage, that is Iodine deficiency can significantly lower the intelligence Quotients (IQ) of a whole population. The most severe impact occurs during fetal development and in the first few years of life. Its consequence is derangement in the development of the brain and the central nervous system which is irreversible with the most serious for being that of cretinism (Chung, 2014). Iodine daily intake is $150 \mu \mathrm{g}$ (Lenntech B.V., 2019).

Copper is present in organ-meat foods, seafood's, nuts, wheat bran cereals, whole grain and seeds. It is absorbed largely in the small intestine although some absorption may take place in the stomach. Absorption varies with copper intake ranging from more than $50 \%$ for intakes below $1 \mathrm{mg} /$ day to less than $20 \%$ for intakes above $2 \mathrm{mg} / \mathrm{day}$ (Lenntech B.V., 2019). The very high levels of zinc or iron taken as supplements generally affects $\mathrm{Cu}$ absorption 
in the body (Botash, Nasca, Dubowy, Weinberger and Oliphant, 1992; Morais, Fisberg, Suzuki, Amancio and Machado, 1994; Turnlund, 1999).

\subsubsection{Calculating the Daily Average Intake based on Dietary Reference}

Considering the per capita rice consumption in 2016/17 estimated at about $35 \mathrm{~kg} / \mathrm{year}$, with Ghana's population at 28.2 million (Global Agricultural Information Network, 2018), then an average daily rice intake is $95.8904 \mathrm{~g} / \mathrm{d}$. Using Pourgheysari formula presented in equation 2 (Pourgheysari, Moazeni, and Ebrahimi, 2012; Mahan and Escott-Stump, 2008; Ireland, Clifton and Keogh, 2010), the daily average intake of the micronutrients when one consumes rice from the five farms is calculated as Table 4.

$$
\text { Daily Intake of Micronutrients }=\text { COMITR } \times \text { MRIGPD }
$$

where COMITR is the concentration of micronutrients in the rice and MRIGPD is the mean rice intake (g/person/day)

Table 4. Calculated mean daily intake of the elements

\begin{tabular}{ccc}
\hline & $\begin{array}{c}\text { Mean Concentration of } \\
\text { Elements }(\mathrm{mg} / \mathrm{kg})\end{array}$ & $\begin{array}{c}\text { Calculated Mean Daily Intake } \\
(\mathrm{mg} / \text { day })\end{array}$ \\
\hline $\mathrm{Na}$ & 160.34 & 15.375 \\
$\mathrm{Mg}$ & 730.8 & 70.077 \\
$\mathrm{Cl}$ & 586.1 & 0.096 \\
$\mathrm{~K}$ & 1611.702 & $652,593.484$ \\
$\mathrm{Ca}$ & 2494.6 & 239.208 \\
$\mathrm{~V}$ & 0.113 & 0.011 \\
$\mathrm{Mn}$ & 12.6732 & 1.215 \\
$\mathrm{Cu}$ & 1.2830 & 0.123 \\
$\mathrm{I}$ & 0.1293 & 0.012 \\
\hline
\end{tabular}

The calculated mean daily intake of the nine micronutrients values in Table 4 were compared to the Mean and the Maximum Upper Limit (UL) of Recommended Dietary Allowable (RDA) and Adequate Intake (AI) for the all the Life Stage Groups (Tables 1A and2A respectively in Appendix) and the difference in values presented in Tables4A and 5A (also in the Appendix). It will be realised that all the calculated values did not exceed the mean and Upper Tolerable Limit of its RDA except K, for all Life Stage Groups. The calculate $\mathrm{Mg}$ and $\mathrm{Ca}$ also show a high value for infants between 0 to 6 months for normal RDAs but could not go beyond the UL for RDA. Mg for Children between 1 to 3 years and V for females between 9 to 18 years did also exceed the UL for RDAs. Finally, Mn for infants between 0 to 3 years was above the normal RDA values. To determine its effect on the health of the consumer the Health Risk was estimated by calculating the Hazard Index (HI).

\subsubsection{Assessment According to Health Risk Estimation}

The Hazard Index is calculated by comparing the estimated dose (ED) to the Reference Dose RfD (an estimate of a daily consumption level that is likely to be without deleterious effects in a lifetime). It is defined by equation 3 (Laar et al, 2011) as:

$$
\text { The hazard index }(\mathrm{HI})=\frac{\mathrm{ED}}{\mathrm{RfD}} \text {, }
$$

$\mathrm{HI}<1$ suggests an improbable unfavourable health effects whereas $\mathrm{HI}>1$ suggests the probability of adverse health effect (Laar et al, 2011). The calculated HI which estimates the health risk associated with the consumption of the rice is presented in Table 6A (in Appendix). It will be seen that apart from the sections that could not be determined due to lack of data (ND) all the calculated values for all the micronutrients were less than 1, suggesting there is no probability of adverse health effects for all life stage groups. The only $\mathrm{HI}>1$ was for Mg (children between the ages of 1 and 3). As said earlier all these elements investigated are essential to human health but can be toxic at concentrations higher than that necessary for the biological functions of the growth processes. Table 1 lists the functions of the elements in the human body and their effects when consumed in deficient or in excessive amounts. 


\section{Conclusion}

This work has imparted knowledge on the levels of $\mathrm{Na}, \mathrm{Mg}, \mathrm{Cl}, \mathrm{K}, \mathrm{Ca}, \mathrm{V}, \mathrm{Mn}, \mathrm{Cu}$ and I present in Jasmine 85 rice grown in five farms in the South-Eastern part of Ghana. This rice type was studied because it is one of the most widely patronized rice by the local residents. The NAA method applied in the analysis of the reference materials IAEA-530 Tuna fish homogenate and NIST USA 1566b Oyster Tissue in order to check the accuracy and reproducibility. This method can accurately determine the content of these nine micronutrients in rice and can be used as traceability of producing area.

The dietary assessment done we hope has thrown more light on the nine micronutrients in the rice farms in the south-eastern part of Ghana. It is recommended that nutritionists; toxicologists and scientists of different background get together and look at the low levels of Iodine in the rice, since its deficiency disorder, IDD, among children may slow down the intentions of the educational restructuring programme and the nation's developmental efforts (Caulfield, Richard, Rivera, Musgrove, and Black, 2006). This will go a long way in helping the country to solve its nutritional and health-related problems.

\section{Acknowledgment}

The authors wish to thank the technicians and staff of Ghana Atomic Energy Commission at Kwabenya - Accra, for their kind support during the data collection and analysis of the samples.

\section{References}

Abbas, M., Atiq-ur-Rahman, M., Manzoor, F., \& Farroq, A. (2015). Pure Appl. Bio, 1(1), 14-15.

Adomako, D., Nyarko, B. J. B., Dampare, S. B., Serfor-Armah, Y., Osae, S., Fianko, J. R., \& Akaho, E. H. K. (2008). Environ. Monit. Assess. 141, 165. https://doi.org/10.1007/s10661-007-9885-x

Adu, P., \& Simpong, D. L. (2017). Addressing the challenge of iodine deficiency in developing countries. MOJ Public Health, 5(3), 89-91. https://doi.org/10.15406/mojph.2017.05.00129

Akintayo, O. T., Maalekuu B. K., \& Saajah J. K. (2019). Jasmine 85 from Seven Rice Seed Production Sources in Ghana Are Genetically Different. Journal of Agricultural Science, 7(4). https://doi.org/10.5539/jas.v7n4p152

Alfassi, Z. B. (1994). Chemical Analysis by Nuclear Methods. John Wiley and Sons.

Ali, M. A. (1999). A Brief Overview of Neutron Activation Analyses Methodology and Applications, 2nd Conference on Nuclear and Particle Physics, 13 -17 Nov. 1999, Cairo, Egypt, pp 71 - 84. Retrieved from http://www.iaea.org/inis/collection/NCLCollectionStore/_Public/37/118/37118483.pdf

Amuah, C. L. Y., Eghan, J. M., Anderson, B., Adueming, P. O. W., \& Opoku-Ansah, J. (2017, September). Laser Induced Fluorescence in combination with Multivariate analysis classifies anti-malarial herbal plants. In Frontiers in Optics (pp. JTu2A-71). Optical Society of America. https://doi.org/10.1364/FIO.2017.JTu2A.71

ATSDR. (2012). Toxicological profile for Vanadium. Atlanta, GA: U.S. Department of Health and Human Services, Public Health Service.

Beebe, K. R., Pell, R. J., \& Seasholtz, M. B. (1998). Chemometrics: a practical guide (Vol. 4). Wiley-Interscience.

Bista, D. R., Heckathorn, S. A., Jayawardena, D. M., Mishra, S., \& Boldt, J. K. (2018). Effects of Drought on Nutrient Uptake and the Levels of Nutrient-Uptake Proteins in Roots of Drought-Sensitive and -Tolerant Grasses, Plants, 7, 28. https://doi.org/10.3390/plants7020028

Botash, A. S., Nasca, J., Dubowy, R., Weinberger, H. L., \& Oliphant, M. (1992). Zinc-induced copper deficiency in an infant. American Journal of Diseases of Children, 146(6), 709-711. https://doi.org/10.1001/archpedi.1992.02160180069019

Bro, R., \&Smilde, A. K. (2014). Principal component analysis. Anal. Methods, (6), 2812. https://doi.org/10.1039/C3AY41907J

Busse M. (2015). Signs and Symptoms of Too Much Magnesium. Retrieved from http://www.livestrong.com/article/379016-signs-and-symptoms-of-too-much-magnesium/

Cannon, H. L., Papp C. S. E., \& Anderson, B. M. (1972). Acad. Sci., 199, 124. https://doi.org/10.1111/j.17496632.1972.tb46449.x

Caulfield, L. E., Richard, S. A., Rivera, J. A., Musgrove, P., \& Black, R. E. (2006). Chapter 28, Stunting, Wasting, and Micronutrient Deficiency Disorders, Disease Control Priorities in Developing Countries (2nd ed.). Oxford University Press. 
Chung, H. R. (2014). Iodine and thyroid function. Ann Pediatr Endocrinol Metab, 19(1), 8-12. https://doi.org/10.6065/apem.2014.19.1.8

Codex. (1996). Codex Standard 198-1995 Standard for Rice. Retrieved from http://www.fao.org/fao-whocodexalimentarius/shproxy/en/?lnk=1\&url=https\%253A\%252F\%252Fworkspace.fao.org\%252Fsites\%252Fcodex\%252FStandar ds\%252FCODEX\%2BSTAN\%2B198-1995\%252FC XS_198e.pdf

Currie, L. A. (1991). The importance of chemometrics in biomedical measurements. In K. S. Subramamanian, K. Okamoto, \& G. V. Iyengar (Eds.), Biomedical Trace Element Research: American College of Surgeons Symposium Series (pp. 72-100). Washington, DC: American Chemical Society. https://doi.org/10.1021/bk1991-0445.ch006

Das, S. K. (2014). Role of Micronutrient in Rice Cultivation and Management Strategy in Organic Agriculture-A Reappraisal. Agricultural Sciences, 5, 765-769. https://doi.org/10.4236/as.2014.59080

Davis, Z. (2019). What Is Calcium-Vitamin D? Everyday Health. Retrieved from https://www.everydayhealth.com/drugs/calcium-vitamin-d

Delange, F., \& Bürgi, H. (1989). Iodine deficiency disorders in Europe. Bulletin of the World Health Organization, $67,317-325$.

Endocrineweb. (2017). How Your Thyroid Works, Vertical Health LLC. Retrieved from https://www.endocrineweb.com/conditions/thyroid/how-your-thyroid-works

Fine, K. D., Santa Ana, C. A., Porter, J. L., \& Fordtran, J. S. (1991). Intestinal absorption of magnesium from food and supplements. The Journal of clinical investigation, 88(2), 396-402. https://doi.org/10.1172/JCI115317

Food and Nutrition Board. (2001). Intake Applications in Dietary Assessment. Washington, DC: National Academy Press.

Ghana Export Promotion Authority. (2018). A Glance at Local Rice Production. Retrieved from https://www.gepaghana.org/glance-local-rice-production/

Glascock, M. A. (2003). An overview of neutron activation analysis. Retrieved from https://www.researchgate.net/publication/228643668_An_overview_of_neutron_activation_analysis

Global Agricultural Information Network. (2018). Ghana - Grain and Feed Update. Retrieved from https://gain.fas.usda.gov/Recent\%20GAIN\%20Publications/Grain\%20and\%20Feed\%20Update_Accra_Gha na_2-2-2018.pdf

Gums, J. G. (2004). Magnesium in cardiovascular and other disorders. American journal of health-system pharmacy, 61(15), 1569-1576. https://doi.org/10.1093/ajhp/61.15.1569

Harvard University. (2019). How much calcium do you really need? Retrieved from https://www.health.harvard.edu/staying-healthy/how-much-calcium-do-you-really-need

Health supplements nutritional guide. (2017). Sodium, Nutritional Health Resource. Retrieved from https://healthsupplementsnutritionalguide.com/?s=sodium, Assessed 07-02-2019

Healthline. (2019). How Much Potassium Do You Need Per Day? Retrieved from https://www.healthline.com/nutrition/how-much-potassium-per-day\#section3

Hemphill, D. D. (1972). Ann. N.Y. Acad. Sci., 199, 46. https://doi.org/10.1111/j.1749-6632.1972.tb46442.x

Institute of Medicine. (2001). Dietary Reference Intakes for Vitamin A, Vitamin K, Arsenic, Boron, Chromium, Copper, Iodine, Iron, Manganese, Molybdenum, Nickel, Silicon, Vanadium, and Zinc. Washington, DC: The National Academies Press.

Ireland, D. M., Clifton, P. M., \& Keogh, J. B. (2010). Achieving the salt intake target of $6 \mathrm{~g} /$ day in the current food supply in free-living adults using two dietary education strategies. Journal of the American Dietetic Association, 110(5), 763-767. https://doi.org/10.1016/j.jada.2010.02.006

Kelly, R. P., \& Moran, S. B. (2002). Seasonal changes in groundwater input to a well - mixed estuary estimated using radium isotopes and implications for coastal nutrient budgets. Limnology and Oceanography, 47(6), 1796-1807. https://doi.org/10.4319/lo.2002.47.6.1796

Koutras, D. A. et. al. (1985). Goitre and iodine deficiency in Europ. Effect of D-Thyroxine on thyrotoxicosis and or the associate exophthalmos. Alexander, W. D. Retrieved from htpp://en.scientificcommons.org 
Laar, C., Fianko, J. R., Akiti, T. T., Osae, S., \& Brimah, A. K. (2011). Determination of heavy metals in the blackchin tilapia from the Sakumo Lagoon, Ghana. Research Journal of Environmental and Earth Sciences, 3(1), $8-13$.

Lenntech, B. V. (2019). Recommended daily intake of vitamins and minerals. Retrieved from https://www.lenntech.com/recommended-daily-intake.htm

Mahan, L. K., \& Escott-Stump, S. (2008). Krause's food and nutrition therapy (11th ed.). Philadelphia, USA: Elsevier Saunders. 900-916.

Merriam-Webster Medical Dictionary. (2015). Dietary Reference Intake. Retrieved from http://www.merriamwebster.com/medical/dietary\%20reference\%20intake

Minerals Education Coalition. (2013). The Role of Minerals and Elements in Life Processes. Retrieved from http://www.mineralseducationcoalition.org/pdfs/Minerals_ElementsNutrition.pdf

Morais, M. B., Fisberg, M., Suzuki, H. U., Amancio, O. M. S., \& Machado, N. L. (1994). Effects of oral iron therapy on serum copper and serum ceruloplasmin in children. Journal of tropical pediatrics, 40(1), 51-52. https://doi.org/10.1093/tropej/40.1.51

Murray, M. T. (2005). Encyclopaedia of Nutritional Supplements, the Essential Guide for Improving Your Health Naturally. Roseville, California: Prima Publishing.

National Health and Medical Research Council [NHRMC]. (2015). Magnesium in diet: MedlinePlus Medical Encyclopedia. Retrieved from https://www.nlm.nih.gov/medlineplus/ency/article/002423.htm

Nishizawa, Y., Morii, H., \& Durlach, J. (2007). New perspectives in magnesium research. London: Springer-Verlag. https://doi.org/10.1007/978-1-84628-483-0

Nolan, K. R. (1983). Copper toxicity syndrome. Journal of Orthomolecular Psychiatry, 12(4), 270-282.

Nyarko, B. J. B., Serfor-Armah, Y., Akaho, E. H. K., Anim-Sampong, S., \& Maakuu, B. T. (2002). Epiboron Instrumental Neutron Activation Analysis of Iodine in various salt samples. J. Radioanal. \& Nucl. Chem., 251(2), 253-257. https://doi.org/10.1023/A:1014868327556

Pallant, J. (2007). SPSS Survival Manual: A Step to Step Guide to Data Analysis using SPSS for Windows (3rd ed.). Open University Press, New York, USA. Pp 132-133.

Palsdottir, H. (2016). 6 Little-Known Dangers of Restricting Sodium Too Much. Healthline. Retrieved from https://www.healthline.com/nutrition/6-dangers-of-sodium-restriction

Pourgheysari, H., Moazeni, M., \& Ebrahimi, A. (2012). Heavy metal content in edible salts in Isfahan and estimation of their daily intake via salt consumption. International Journal of Environmental Health Engineering, 1(1), 8. https://doi.org/10.4103/2277-9183.94392

Raman, R. (2017). What Does Potassium Do for Your Body? A Detailed Review. Retrieved from https://www.healthline.com/nutrition/what-does-potassium-do

Royal Society of Chemistry [RSC]. (2015). Magnesium, Uses and Properties. Retrieved from http://www.rsc.org/periodic-table/element/12/magnesium

Rumsey, J. D. (2010). Statistics for Dummies. Wiley Publishing, Inc., USA. pg 117.

Sauchelli, V. (1969). Trace Elements in Agriculture. Van Nostrand Reinhold Co.

Sharecare. (2019). What is the role of calcium in my body? Retrieved from https://www.sharecare.com/health/calcium-nutrients/role-of-calcium-in-body

Tandoh, J. B., Bredwa-Mensah, Y., Dampare, S. B., Akaho, E. H. K., \& Nyarko, B. J. B. (2009). Chemical characterization of ancient pottery from the greater Accra region of Ghana using neutron activation analysis. Nuclear Instruments and Methods in Physics Research Section B: Beam Interactions with Materials and Atoms, 267(11), 1924-1930. https://doi.org/10.1016/j.nimb.2009.03.098

Teherani, D. K. (1987). Trace Elements Analysis In Rice. J.Radioanal.Nucl.Chem., Letters 117 /3/133-143. https://doi.org/10.1007/BF02165367

The National Academies. (2005). Dietary Reference Intakes for Water, Potassium, Sodium, Chloride, and Sulfate. Retrieved from www.nap.edu

Thomas, L. (2019). Should We Eat Polished Rice? News-Medical. Retrieved from https://www.newsmedical.net/health/Should-We-Eat-Polished-Rice.aspx 
Tracey, A. S., Willsky, G. R., \& Takeuchi, E. S. (2007). Vanadium: chemistry, biochemistry, pharmacology and practical applications. Boca Raton, FL: CRC press. https://doi.org/10.1201/9781420046144

Turnlund, J. R. (1999). Copper. In M. E. Shils, J. A. Olson, M. Shike, \& A. C. Ross (Eds), Modern nutrition in health and disease (9th ed., pp. 241-252). Baltimore: Williams \& Wilkins.

U.S. Department of Health \& Human Services. (2016). Iodine Fact Sheet for Consumers. Retrieved from https://ods.od.nih.gov/factsheets/Iodine-Consumer/

U.S. National Library of Medicine. (2019). Manganese. Retrieved fromhttps://medlineplus.gov/druginfo/natural/182.html

University Health News. (2019). 21 Calcium Deficiency Symptoms That Will Surprise You. Retrieved from https://universityhealthnews.com/daily/nutrition/21-calcium-deficiency-symptoms-that-will-surprise-you/

US EPA. (2015). Human Health Ambient Water Quality Criteria: 2015 Update. Retrieved from https://www.epa.gov/sites/production/files/2015-10/documents/human-health-2015-updatefactsheet.pdf

US FDA. (2019). Use the Nutrition Facts Label to Reduce Your Intake of Sodium in Your Diet. Retrieved from https://www.fda.gov/food/nutrition-education-resources-and-materials/use-nutrition-facts-label-reduceyour-intake-sodium-your-diet

Vowotor, M. K., Hood C. O., Owusu, A., Akakpo, E. H., \& Mireku, K. K. (2012). Determination of Mn, Cu, and $\mathrm{Na}$ in Sarotherodon Melanotheron (Blackchin Tilapia) From the Fosu Lagoon, Cape Coast - Ghana, Using Instrumental Neutron Activation Analysis (INAA). The African Review of Physics, APR, 7, pp 367-375.

White rice. (2019). Retrieved from https://en.wikipedia.org/wiki/White_rice

\section{Appendix}

Table 1A. Measured concentrations of the 9 elements at the 5 Rice farms in $\mathrm{mg} / \mathrm{kg}$

\begin{tabular}{clllllll}
\hline Elements & $\begin{array}{l}\text { Afienya } \\
\text { Farms }\end{array}$ & $\begin{array}{l}\text { Afife } \\
\text { Farms }\end{array}$ & $\begin{array}{l}\text { Dawhenya } \\
\text { Farms }\end{array}$ & $\begin{array}{l}\text { Ashaiman } \\
\text { Farms }\end{array}$ & $\begin{array}{l}\text { Aveyime } \\
\text { Farms }\end{array}$ & $\begin{array}{l}\text { Mean } \\
\text { Value }\end{array}$ & $\begin{array}{l}\text { SD } \\
\text { Value }\end{array}$ \\
\hline $\mathrm{Na}$ & 153.4000 & 167.6000 & 142.3000 & 150.3000 & 188.1000 & 160.34 & 18.0120 \\
$\mathrm{Mg}$ & 759.3000 & 483.2000 & 875.7000 & 719.5000 & 816.6000 & 730.8 & 150.5019 \\
$\mathrm{Cl}$ & 492.0000 & 718.0000 & 465.6000 & 636.8000 & 618.1000 & 586.1 & 105.3176 \\
$\mathrm{~K}$ & 875.2000 & 2281.0000 & 514.6000 & 1438.7057 & 2949.0000 & 1611.702 & 1001.539 \\
$\mathrm{Ca}$ & 2541.0000 & 2303.0000 & 2455.0000 & 2622.0000 & 2552.0000 & 2494.6 & 122.4308 \\
$\mathrm{~V}$ & 0.0698 & 0.1091 & 0.1023 & 0.1020 & 0.1925 & 0.113 & 0.0482 \\
$\mathrm{Mn}$ & 9.9560 & 14.4600 & 14.3500 & 11.4700 & 13.1300 & 12.6732 & 1.9393 \\
$\mathrm{Cu}$ & 0.8728 & 1.6790 & 1.3440 & 1.6420 & 0.8771 & 1.2830 & 0.3945 \\
$\mathrm{I}$ & 0.1211 & 0.1181 & 0.1277 & 0.1447 & 0.1351 & 0.1293 & 0.0108 \\
\hline
\end{tabular}


Table 2A. Recommended Dietary Allowable (RDA) and Adequate Intake (AI) for the Life Stage Groups (Food and Nutrition Board, 2001; Institute of Medicine, 2001)

\begin{tabular}{llccccccccc}
\hline \multicolumn{2}{l}{ Life Stage Group } & $\mathrm{Na}$ & $\mathrm{Mg}$ & $\mathrm{Cl}$ & $\mathrm{K}$ & $\mathrm{Ca}$ & $\mathrm{V}$ & $\mathrm{Mn}$ & $\mathrm{Cu}$ & $\mathrm{I}$ \\
\hline \multirow{2}{*}{ Infants } & 0-6months & 120 & 30 & 180 & 400 & 200 & $\mathrm{ND}$ & 0.003 & 0.2 & 0.11 \\
& $7-12 \mathrm{months}$ & 370 & 75 & 570 & 860 & 260 & $\mathrm{ND}$ & 0.6 & 0.22 & 0.13 \\
\hline Children & $1-3 \mathrm{y}$ & 1000 & 80 & 1500 & 2000 & 700 & $\mathrm{ND}$ & 1.2 & 0.34 & 0.09 \\
& $4-8 \mathrm{y}$ & 1200 & 130 & 1900 & 2300 & 1000 & $\mathrm{ND}$ & 1.5 & 0.44 & 0.09 \\
\hline Males & $9-13 \mathrm{y}$ & 1500 & 240 & 2300 & 2500 & 1300 & $\mathrm{ND}$ & 1.9 & 0.7 & 0.12 \\
& $14-18 \mathrm{y}$ & 1500 & 410 & 2300 & 3000 & 1300 & $\mathrm{ND}$ & 2.2 & 0.89 & 0.15 \\
& $19-30 \mathrm{y}$ & 1500 & 400 & 2300 & 3400 & 1000 & $\mathrm{ND}$ & 2.3 & 0.9 & 0.15 \\
& $31-50 \mathrm{y}$ & 1500 & 420 & 2300 & 3400 & 1000 & $\mathrm{NDN}$ & 2.3 & 0.9 & 0.15 \\
& $50-70 \mathrm{y}$ & 1300 & 420 & 2000 & 3400 & 1000 & $\mathrm{D}$ & 2.3 & 0.9 & 0.15 \\
& $>70 \mathrm{y}$ & 1200 & 420 & 1800 & 3400 & 1200 & $\mathrm{ND}$ & 2.3 & 0.9 & 0.15 \\
\hline \multirow{6}{*}{ Females } & $9-13 \mathrm{y}$ & 1500 & 240 & 2300 & 2300 & 1300 & $\mathrm{ND}$ & 1.6 & 0.7 & 0.12 \\
& $14-18 \mathrm{y}$ & 1500 & 410 & 2300 & 2300 & 1300 & $\mathrm{ND}$ & 1.6 & 0.89 & 0.15 \\
& $19-30 \mathrm{y}$ & 1500 & 400 & 2300 & 2600 & 1000 & $\mathrm{ND}$ & 1.8 & 0.9 & 0.15 \\
& $31-50 \mathrm{y}$ & 1500 & 420 & 2300 & 2600 & 1000 & $\mathrm{NDN}$ & 1.8 & 0.9 & 0.15 \\
& $50-70 \mathrm{y}$ & 1300 & 420 & 2000 & 2600 & 1200 & $\mathrm{D}$ & 1.8 & 0.9 & 0.15 \\
& $>70 \mathrm{y}$ & 1200 & 420 & 1800 & 2600 & 1200 & $\mathrm{ND}$ & 1.8 & 0.9 & 0.15 \\
\hline \multirow{6}{*}{ Wactation } & $\leq 18 \mathrm{y}$ & 1500 & 360 & 2300 & 2500 & 1300 & $\mathrm{ND}$ & 2.6 & 1.3 & 0.29 \\
& $19-30 \mathrm{y}$ & 1500 & 310 & 2300 & 2800 & 1000 & $\mathrm{ND}$ & 2.6 & 1.3 & 0.29 \\
& $31-50 \mathrm{y}$ & 1500 & 320 & 2300 & 2800 & 1000 & $\mathrm{ND}$ & 2.6 & 1.3 & 0.29 \\
\hline \multirow{6}{*}{ Pregnant } & $\leq 18 \mathrm{y}$ & 1500 & 400 & 2300 & 2600 & 1300 & $\mathrm{ND}$ & 2.0 & 1 & 0.22 \\
& $19-30 \mathrm{y}$ & 1500 & 350 & 2300 & 2900 & 1000 & $\mathrm{ND}$ & 2.0 & 1 & 0.22 \\
& $31-50 \mathrm{y}$ & 1500 & 360 & 2300 & 2900 & 1000 & $\mathrm{ND}$ & 2.0 & 1 & 0.22 \\
\hline
\end{tabular}


Table 3A. Maximum Upper Limit (UL) of Recommended Dietary Allowable (RDA) and Adequate Intake(AI) for the Life Stage Groups (Food and Nutrition Board, 2001; Institute of Medicine, 2001)

\begin{tabular}{|c|c|c|c|c|c|c|c|c|c|c|}
\hline & \multirow{2}{*}{$\begin{array}{c}\mathrm{Na} \\
R D A / A I \\
(\mathrm{mg} / \mathrm{d})\end{array}$} & \multirow{2}{*}{$\begin{array}{c}{ }^{b} \mathrm{Mg} \\
R D A / A I \\
(\mathrm{mg} / \mathrm{d})\end{array}$} & \multirow{2}{*}{$\begin{array}{c}\mathrm{Cl} \\
R D A / A I \\
(\mathrm{mg} / \mathrm{d})\end{array}$} & \multirow{2}{*}{$\begin{array}{c}{ }^{d} \mathrm{~K} \\
A I \\
(\mathrm{mg} / \mathrm{d}) \\
\end{array}$} & \multirow{2}{*}{$\begin{array}{c}\mathrm{Ca} \\
R D A / A I \\
(\mathrm{mg} / \mathrm{d})\end{array}$} & \multirow{2}{*}{$\begin{array}{c}{ }^{d} \mathrm{~V} \\
A I \\
(\mathrm{mg} / \mathrm{d})\end{array}$} & \multirow{2}{*}{$\begin{array}{c}\mathrm{Mn} \\
A I \\
(\mathrm{mg} / \mathrm{d})\end{array}$} & \multirow{2}{*}{$\begin{array}{c}\mathrm{Cu} \\
R D A / A I \\
(\mathrm{mg} / \mathrm{d})\end{array}$} & \multirow{2}{*}{$\begin{array}{c}\mathrm{I} \\
R D A / A I \\
(\mathrm{mg} / \mathrm{d})\end{array}$} \\
\hline Life Stage & Group & & & & & & & & & \\
\hline \multirow[t]{2}{*}{ Infants } & $0-6$ months & ND & ND & ND & ND & 1000 & ND & ND & ND & ND \\
\hline & $7-12$ months & ND & ND & ND & ND & 1500 & ND & ND & ND & ND \\
\hline \multirow[t]{2}{*}{ Children } & $1-3 y$ & 1500 & 65 & 2300 & ND & 2500 & ND & 2 & 1 & 0.2 \\
\hline & $4-8 y$ & 1900 & 110 & 2900 & ND & 2500 & ND & 3 & 3 & 0.3 \\
\hline \multirow[t]{6}{*}{ Males } & $9-13 y$ & 2200 & 350 & 3400 & ND & 3000 & ND & 6 & 5 & 0.6 \\
\hline & $14-18 y$ & 2300 & 350 & 3600 & ND & 3000 & ND & 9 & 8 & 0.9 \\
\hline & $19-30 y$ & 2300 & 350 & 3600 & ND & 2500 & 1.8 & 11 & 10 & 1.1 \\
\hline & $31-50 y$ & 2300 & 350 & 3600 & ND & 2500 & 1.8 & 11 & 10 & 1.1 \\
\hline & $50-70 y$ & 2300 & 350 & 3600 & ND & 2000 & 1.8 & 11 & 10 & 1.1 \\
\hline & $>70 y$ & 2300 & 350 & 3600 & ND & 2000 & 1.8 & 11 & 10 & 1.1 \\
\hline \multirow[t]{6}{*}{ Females } & $9-13 y$ & 2200 & 350 & 3400 & ND & 3000 & ND & 6 & 5 & 0.6 \\
\hline & $14-18 y$ & 2300 & 350 & 3600 & ND & 3000 & ND & 9 & 8 & 0.9 \\
\hline & $19-30 y$ & 2300 & 350 & 3600 & ND & 2500 & 1.8 & 11 & 10 & 1.1 \\
\hline & $31-50 y$ & 2300 & 350 & 3600 & ND & 2500 & 1.8 & 11 & 10 & 1.1 \\
\hline & $50-70 y$ & 2300 & 350 & 3600 & ND & 2000 & 1.8 & 11 & 10 & 1.1 \\
\hline & $>70 y$ & 2300 & 350 & 3600 & ND & 2000 & 1.8 & 11 & 10 & 1.1 \\
\hline Pregnant & $\leq 18 \mathrm{y}$ & 2300 & 350 & 3600 & ND & 3000 & ND & 9 & 8 & 0.9 \\
\hline \multirow[t]{2}{*}{ Women } & $19-30 y$ & 2300 & 350 & 3600 & ND & 2500 & ND & 11 & 10 & 1.1 \\
\hline & $31-50 y$ & 2300 & 350 & 3600 & ND & 2500 & ND & 11 & 10 & 1.1 \\
\hline Lactation & $\leq 18 \mathrm{y}$ & 2300 & 350 & 3600 & ND & 3000 & ND & 9 & 8 & 0.9 \\
\hline \multirow[t]{2}{*}{ Women } & $19-30 y$ & 2300 & 350 & 3600 & ND & 2500 & ND & 11 & 10 & 1.1 \\
\hline & $31-50 y$ & 2300 & 350 & 3600 & ND & 2500 & ND & 11 & 10 & 1.1 \\
\hline
\end{tabular}

\section{Note:}

${ }^{b}$ The UL for magnesium represents intake from a pharmacological agent only and does not include intake from food and water.

${ }^{d}$ Although vanadium in food has not been shown to cause adverse effects in humans, there is nojustification for adding it to food. Its supplements should be used with caution. The UL is based on adverse effects in laboratory animals and this datacould be used to set an UL for adults but not children or adolescents.

ND = Not determinable due to lack of data of adverse effects in this age group and concern with regard to lack of ability to handle excess amounts. Source of intake should be fromfood only to prevent high levels of intake (Food and Nutrition, 2005). 
Table 4A. Differences between the RDA / AI and the Calculated Meansfor the Life Stage Groups

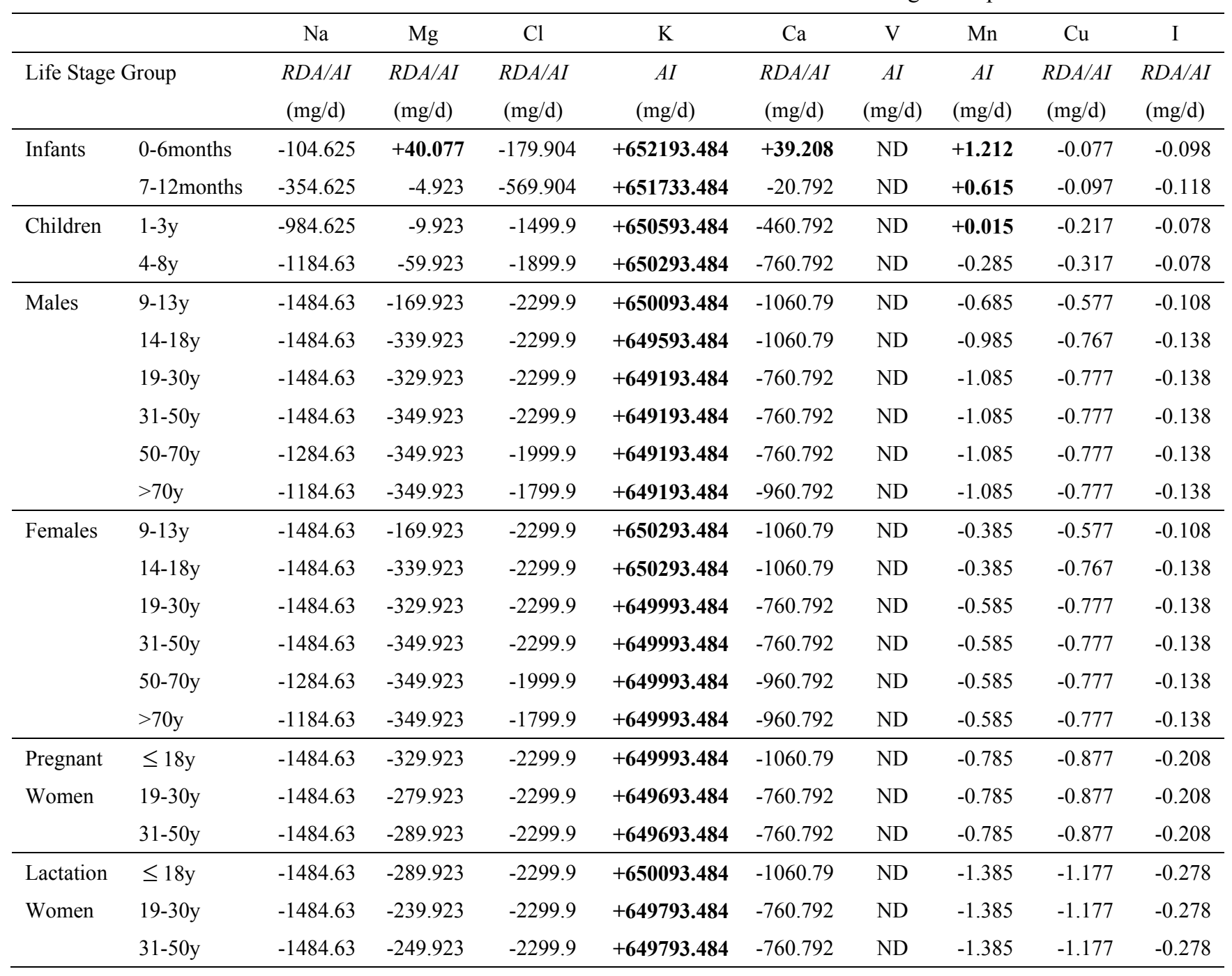


Table 5A. Differences between the UL of the RDA / AI and the Calculated Means for the Life Stage Groups

\begin{tabular}{|c|c|c|c|c|c|c|c|c|c|c|}
\hline & & $\mathrm{Na}$ & ${ }^{b} \mathrm{Mg}$ & $\mathrm{Cl}$ & ${ }^{d} \mathrm{~K}$ & $\mathrm{Ca}$ & ${ }^{d} \mathrm{~V}$ & $\mathrm{Mn}$ & $\mathrm{Cu}$ & I \\
\hline \multicolumn{2}{|c|}{ Life Stage Group } & $R D A / A I$ & $R D A / A I$ & $R D A / A I$ & $A I$ & $R D A / A I$ & $A I$ & $A I$ & $R D A / A I$ & $R D A / A I$ \\
\hline \multirow{3}{*}{ Infants } & & & & & & & & & & \\
\hline & 0-6months & ND & ND & ND & ND & -760.79 & ND & ND & ND & ND \\
\hline & 7-12months & ND & ND & ND & ND & -1260.79 & ND & ND & ND & ND \\
\hline \multirow[t]{2}{*}{ Children } & $1-3 y$ & -1484.63 & 5.077 & -2299.9 & ND & -2260.79 & ND & -0.785 & -0.877 & -0.188 \\
\hline & $4-8 \mathrm{y}$ & -1884.63 & -39.923 & -2899.9 & ND & -2260.79 & ND & -1.785 & -2.877 & -0.288 \\
\hline \multirow[t]{6}{*}{ Males } & $9-13 y$ & -2184.63 & -279.923 & -3399.9 & ND & -2760.79 & ND & -4.785 & -4.877 & -0.588 \\
\hline & $14-18 y$ & -2284.63 & -279.923 & -3599.9 & ND & -2760.79 & ND & -7.785 & -7.877 & -0.888 \\
\hline & $19-30 y$ & -2284.63 & -279.923 & -3599.9 & ND & -2260.79 & -1.79 & -9.785 & -9.877 & -1.088 \\
\hline & $31-50 y$ & -2284.63 & -279.923 & -3599.9 & ND & -2260.79 & -1.79 & -9.785 & -9.877 & -1.088 \\
\hline & $50-70 y$ & -2284.63 & -279.923 & -3599.9 & ND & -1760.79 & -1.79 & -9.785 & -9.877 & -1.088 \\
\hline & $>70 y$ & -2284.63 & -279.923 & -3599.9 & ND & -1760.79 & -1.79 & -9.785 & -9.877 & -1.088 \\
\hline \multirow[t]{6}{*}{ Females } & $9-13 y$ & -2184.63 & -279.923 & -3399.9 & ND & -2760.79 & +0.011 & -4.785 & -4.877 & -0.588 \\
\hline & $14-18 y$ & -2284.63 & -279.923 & -3599.9 & ND & -2760.79 & +0.011 & -7.785 & -7.877 & -0.888 \\
\hline & $19-30 y$ & -2284.63 & -279.923 & -3599.9 & ND & -2260.79 & -1.789 & -9.785 & -9.877 & -1.088 \\
\hline & $31-50 y$ & -2284.63 & -279.923 & -3599.9 & ND & -2260.79 & -1.789 & -9.785 & -9.877 & -1.088 \\
\hline & $50-70 y$ & -2284.63 & -279.923 & -3599.9 & ND & -1760.79 & -1.789 & -9.785 & -9.877 & -1.088 \\
\hline & $>70 y$ & -2284.63 & -279.923 & -3599.9 & ND & -1760.79 & -1.789 & -9.785 & -9.877 & -1.088 \\
\hline Pregnant & $\leq 18 \mathrm{y}$ & -2284.63 & -279.923 & -3599.9 & ND & -2760.79 & ND & -7.785 & -7.877 & -0.888 \\
\hline \multirow[t]{2}{*}{ Women } & $19-30 y$ & -2284.63 & -279.923 & -3599.9 & ND & -2260.79 & ND & -9.785 & -9.877 & -1.088 \\
\hline & $31-50 y$ & -2284.63 & -279.923 & -3599.9 & ND & -2260.79 & ND & -9.785 & -9.877 & -1.088 \\
\hline Lactation & $\leq 18 \mathrm{y}$ & -2284.63 & -279.923 & -3599.9 & ND & -2760.79 & ND & -7.785 & -7.877 & -0.888 \\
\hline \multirow[t]{2}{*}{ Women } & $19-30 y$ & -2284.63 & -279.923 & -3599.9 & ND & -2260.79 & ND & -9.785 & -9.877 & -1.088 \\
\hline & $31-50 y$ & -2284.63 & -279.923 & -3599.9 & ND & -2260.79 & ND & -9.785 & -9.877 & -1.088 \\
\hline
\end{tabular}

Note: The negative sign (-) denotes that the values are below the RDA/AI or ULs, whiles the positive sign (+) denotes that the values are above the RDA/AI or ULs. 
Table 6A. Health Risk Estimates Associated with the Rice collected from the 5 Farms for the Life Stage Groups

\begin{tabular}{|c|c|c|c|c|c|c|c|c|c|c|}
\hline & & \multicolumn{9}{|c|}{ Hazard Index } \\
\hline \multicolumn{2}{|c|}{ Life Stage Group } & $\mathrm{Na}$ & $\mathrm{Mg}$ & $\mathrm{Cl}$ & $\mathrm{K}$ & $\mathrm{Ca}$ & ${ }^{d} \mathrm{~V}$ & $\mathrm{Mn}$ & $\mathrm{Cu}$ & I \\
\hline \multirow[t]{2}{*}{ Infants } & $0-6$ months & ND & ND & ND & ND & 0.24 & ND & ND & ND & ND \\
\hline & 7-12months & ND & ND & ND & ND & 0.16 & ND & ND & ND & ND \\
\hline \multirow[t]{2}{*}{ Children } & $1-3 y$ & 0.013 & 1.078 & 4.17E-05 & ND & 0.10 & ND & 0.608 & 0.123 & 0.06 \\
\hline & $4-8 y$ & 0.008 & 0.637 & $3.31 \mathrm{E}-05$ & ND & 0.10 & ND & 0.405 & 0.041 & 0.04 \\
\hline \multirow[t]{6}{*}{ Males } & $9-13 y$ & 0.007 & 0.200 & $2.82 \mathrm{E}-05$ & ND & 0.08 & ND & 0.203 & 0.025 & 0.02 \\
\hline & $14-18 y$ & 0.007 & 0.200 & $2.67 \mathrm{E}-05$ & ND & 0.08 & ND & 0.135 & 0.015 & 0.01 \\
\hline & $19-30 y$ & 0.007 & 0.200 & $2.67 \mathrm{E}-05$ & ND & 0.10 & 0.006 & 0.110 & 0.012 & 0.01 \\
\hline & $31-50 y$ & 0.007 & 0.200 & $2.67 \mathrm{E}-05$ & ND & 0.10 & 0.006 & 0.110 & 0.012 & 0.01 \\
\hline & $50-70 y$ & 0.007 & 0.200 & $2.67 \mathrm{E}-05$ & ND & 0.12 & 0.006 & 0.110 & 0.012 & 0.01 \\
\hline & $>70 y$ & 0.007 & 0.200 & $2.67 \mathrm{E}-05$ & ND & 0.12 & 0.006 & 0.110 & 0.012 & 0.01 \\
\hline \multirow[t]{6}{*}{ Females } & $9-13 y$ & 0.007 & 0.200 & $2.82 \mathrm{E}-05$ & ND & 0.08 & ND & 0.203 & 0.025 & 0.02 \\
\hline & $14-18 y$ & 0.007 & 0.200 & $2.67 \mathrm{E}-05$ & ND & 0.08 & ND & 0.135 & 0.015 & 0.01 \\
\hline & $19-30 y$ & 0.007 & 0.200 & $2.67 \mathrm{E}-05$ & ND & 0.10 & 0.006 & 0.110 & 0.012 & 0.01 \\
\hline & $31-50 y$ & 0.007 & 0.200 & $2.67 \mathrm{E}-05$ & ND & 0.10 & 0.006 & 0.110 & 0.012 & 0.01 \\
\hline & $50-70 y$ & 0.007 & 0.200 & $2.67 \mathrm{E}-05$ & ND & 0.12 & 0.006 & 0.110 & 0.012 & 0.01 \\
\hline & $>70 y$ & 0.007 & 0.200 & $2.67 \mathrm{E}-05$ & ND & 0.12 & 0.006 & 0.110 & 0.012 & 0.01 \\
\hline Pregnant & $\leq 18 \mathrm{y}$ & 0.007 & 0.200 & $2.67 \mathrm{E}-05$ & ND & 0.08 & ND & 0.135 & 0.015 & 0.01 \\
\hline \multirow[t]{2}{*}{ Women } & $19-30 y$ & 0.007 & 0.200 & $2.67 \mathrm{E}-05$ & ND & 0.10 & ND & 0.110 & 0.012 & 0.01 \\
\hline & $31-50 y$ & 0.007 & 0.200 & $2.67 \mathrm{E}-05$ & ND & 0.10 & ND & 0.110 & 0.012 & 0.01 \\
\hline Lactation & $\leq 18 \mathrm{y}$ & 0.007 & 0.200 & $2.67 \mathrm{E}-05$ & ND & 0.08 & ND & 0.135 & 0.015 & 0.01 \\
\hline \multirow[t]{2}{*}{ Women } & $19-30 y$ & 0.007 & 0.200 & $2.67 \mathrm{E}-05$ & ND & 0.10 & ND & 0.110 & 0.012 & 0.01 \\
\hline & $31-50 y$ & 0.007 & 0.200 & $2.67 \mathrm{E}-05$ & ND & 0.10 & ND & 0.110 & 0.012 & 0.01 \\
\hline
\end{tabular}

\section{Copyrights}

Copyright for this article is retained by the author(s), with first publication rights granted to the journal.

This is an open-access article distributed under the terms and conditions of the Creative Commons Attribution license (http://creativecommons.org/licenses/by/4.0/). 